\title{
Phantom Limbs and the Hard Problem
}

In the previous chapters, I have shown how different aspects of bodily alteration may illuminate for us different early modern anxieties and fantasies about the possible uses of the body as a commodity, a relational object, a sign, and a sign-maker. This final chapter will look at a strange phenomenon which affected many surgically altered bodies and posed questions about bodily experience in general. Phantom limb pain (PLP) was an affective phenomenon that was parsed in terms of science, medicine, and philosophy. It provoked those who looked upon it (in person or through the medium of text) to consider what distinguished their own 'real' pains from these 'unreal' bodily sensations. Phantoms provided the most influential natural philosophers of the early modern period with a puzzle in which the role of the body as both subject and object was uppermost.

As Drew Daniel observes of the early modern melancholic, the phantom pain sufferer 'always seems to both require and exceed explanation, at once to need no introduction and to never be able to stop introducing himself. ${ }^{\mathrm{I}}$ In my analysis of the topic, I trace the under- and over-determination of phantom limbs through medical and philosophical works. I will, however, consciously avoid the use of phantom limbs as analogy for that which is missing from literary texts. Phantoms, like prostheses, make useful tools for thought. The 'presence of an absence', as Vivian Sobchack terms this phenomenon, is a provocative way of thinking about how a text's omissions might make meaning. ${ }^{2}$ Yet, I wish to attend to the historical specificities of phantom limb pain, and in particular to the literature that was generated by thinking about phantom limbs. The 'hard problem' of

I Drew Daniel, The Melancholy Assemblage: Affect and Epistemology in the English Renaissance (New York: Fordham University Press, 2013), p. 6.

2 Vivian Sobchack, 'Living a "Phantom Limb": On the Phenomenology of Bodily Integrity', Body and Society I6:3 (2010): 5I-67, https://doi.org/Io.I I77/I 357034XI0373407. 
this chapter's title is a modern phrase, but one of relevance to the quandary felt by seventeenth- and eighteenth-century natural philosophers in regard to the body. Popularised as a term by David Chalmers in the I990s, the hard problem describes the puzzle of how consciousness can arise from matter. As Chalmers describes:

It is undeniable that some organisms are subjects of experience. But the questions of how it is that these systems are subjects of experience is perplexing. Why is it that when our cognitive systems engage in visual and auditory information-processing, we have visual or auditory experience: the quality of deep blue, the sensation of middle C? How can we explain why there is something it's like to entertain a mental image, or to experience an emotion? It is widely agreed that experience arises from a physical basis, but we have no good explanation of why and how it so arises. Why should physical processing give rise to a rich inner life at all? ${ }^{3}$

In modern neuroscience, one can look at a brain scan and see a lighting up' which represents what occurs in the brain when we listen to music, or see the colour red. Nonetheless, it remains unclear how exactly the electrical impulses which flow between synapses generate the subjective, abstract experience of melodic sound, or of 'red'. In early modern investigations of the same question, I will argue, concrete representation of thought - the 'lighting up' of the brain - was provided by bodily phenomena. Anomalous bodies or body parts could provide the most illuminating examples, and phantom limbs were arguably the most anomalous body parts of all. The picture was complicated, moreover, by a fundamental difference between early modern and modern philosophies of mind. Whereas today's neuroscientists commonly seek to find a material process to explain the seemingly immaterial phenomenon of thought, seventeenthand eighteenth-century physicians and philosophers worked against a backdrop of Christian faith which commonly, though not always, assumed the existence of an immaterial and immortal soul as a starting point.

\section{Thinking with Phantoms: Early Modern Theories of Sensation}

The first extant observation of what we now call phantom limb pain appears in Ambroise Paré's 1564 Ten Books of Surgery. ${ }^{4}$ Paré was a skilled

3 David Chalmers, 'The Hard Problem of Consciousness', in The Blackwell Companion to Consciousness, ed. Max Velmans and Susan Schneider (Oxford: Blackwell, 2007), p. 226, https:// doi.org/I0.1002/9780470751466.chi8.

4 I am speaking here of the European medical tradition only. Even within this, it is entirely possible that other works on phantom limb pain exist and have not been studied, or once existed and are no 
and renowned military surgeon, and he drew on his experiences to suggest remedies for common combat injuries such as burns, fractures, and contusions. In the seventh book, on 'gangrene and mortification', he advises surgeons not to be fooled by patients who report feeling pain in limbs which appear gangrenous. Such sensations, he argues, are merely referred, in the same way that tugging on a garment produces a touch on the skin. Further proof of the tricks pain can play on the brain is evident in the complaints of patients after limb amputation:

Of this false feeling you will have manifest argument after the amputation of the mortified parts. For the patients, long after the amputation is made, say they still feel pain in the dead and amputated parts. Of this they complain strongly, a thing worthy of wonder, and almost incredible to people who have not experienced this. ${ }^{5}$

What drove this mysterious pain? Another passage in the same book offers this explanation:

Now, it is so that a long time after the amputation, the patients think they still have in its entirety the member which has been amputated from them (as I have said). This happens to them, as it seems to me, because the nerves withdraw toward their origin and in withdrawing make great pain, almost similar to the retractions which are made in spasms. To remedy this, it is necessary to rub the nape of the neck and the whole affected part with the liniment which follows. ${ }^{6}$

These passages are notable for several reasons. The Ten Books were not published in English, but may nonetheless have been read by many English surgeons, who often received training on the continent, and who were substantially influenced by Parés work. Interestingly, however, the passages were reformulated in the English translation of Paré's Oeuvres (first published as the Workes in 1634). In this translation, the more

longer extant. Certainly, Paré's treatment of the subject implies that he thought other surgeons would be familiar with the phenomenon he describes.

5 Ambroise Paré, Ten Books of Surgery with the Magazine of the Instruments Necessary for It, trans. Robert White Linker and Nathan Womack (Athens: University of Georgia Press, 2010), p. I34. This translation was first published in 1969. Prior to this, the work (published in French in I 564) had not been translated into English, though it is likely to have been read by some English surgeons in the original language, or in the Latin version. Linker and Womack speculate that the reason it was not translated in the early modern period is because most of the material therein was included in some form in Parés Oeuvres and thus in the (widely available) Workes.

6 Ibid., p. I42. The liniment Paré mentions is a concoction of sage, marjoram, rosemary, mint, rue, lavender, camomile, dill, hypericum, laurel, juniper, pellitory, mastic, laserwort, Venice turpentine, 'sweet gum', oil of earthworms, oil of puppies, oil of turpentine, human fat, crocus, white wine, and wax. 
detailed aspects of this explanation for phantom limbs were omitted, and emphasis was instead placed on the mystery which surrounded this strange phenomenon. Again, the passage was positioned as a warning to surgeons about patients who reported sensation in gangrenous limbs:

Here I must admonish the young Chirurgeon, that he be not deceived concerning the loss, or privation, of the sense of the part. For I know very many deceived as thus; the Patients pricked on that [gangrenous] part would say, they felt much pain there. But that feeling is oft deceitful, as that which proceeds rather from the strong apprehension of great pain which formerly raigned in the part, than from any faculty of feeling as yet remaining. A most clear and manifest argument of this false and deceitful sense appears after the amputation of the member; for a long while after they will complain of the part which is cut away.

Verily it is a thing wondrous strange and prodigious, and which will scarse be credited, unless by such as have seen with their eyes, and heard with their ears the Patients, who have many months after the cutting away of the Leg, grevously complained that they yet felt exceeding great pain of that Leg so cut off. ${ }^{7}$

This passage clearly takes much from the first example cited from Ten Bookes. However, it substantially adds to that passage, and the choice of language by both author and translator here is worth unpacking. ${ }^{8}$ Multiple parties are in danger of 'deception': the patient, the surgeon, and the reader/viewer. Yet Parés description itself reinforces the 'existence' of the phantom limb. The various onlookers in this case must 'see with their eyes' and 'hear with their ears' to know the case reliably. However, the phantom pain sufferer, by Paré's own admission, feels 'with her limb', inasmuch as they complain 'of the Leg' as distinct from the stump. To 'apprehend' in this period means 'to lay hold of in many different senses: to restrain with the hands, to grasp with the intellect, to perceive sensorially, to feel emotionally, and to learn of. ${ }^{9}$ The translator's choice of this term thus

7 Ambroise Paré, The Workes of That Famous Chirurgion Ambrose Parey Translated out of Latine and Compared with the French. by Th: Johnson (London: printed by Th. Cotes and R. Young, I634), p. 457.

8 The influence of the translator on this text may need further study - a brief but informative article from the James Lind Library suggests that 'It is unfortunate that this, the only fairly complete English edition of Paré's works, was derived from the less than perfect Latin editions; though the title claims "compared with the French" it seems that Johnson's French was not equal to the task. In spite of this, the Jacobean English of the translation suits Paré's often racy style very well and the book is in many ways delightful, if not always very accurate.' 'Paré A (I 575)', James Lind Library, 26 May 2010, accessed 7 November 2019, www.jameslindlibrary.org/pare-a-I 575/.

9 'Apprehension, N.', in OED Online (Oxford University Press), accessed 4 August 2017, www.oed $. \mathrm{com} / \mathrm{view} /$ Entry/9808. 
reflects the multivalency of the phantom, which is at once absent and present, unable to be apprehended by the eye and unable to stop being apprehended by nociception. Likewise, this phenomenon is at once 'prodigious' (that is, both 'causing wonder' and 'portentous', with connotations of the supernatural), and a natural response to be expected by the diligent surgeon. ${ }^{\text {IO }}$

In the Workes, Paré's description of the phantom limb was pragmatic, but clearly fascinated by the 'wondrous strange[ness]' of the phenomenon. However, his earlier analysis of 'spasms' as the cause of PLP was ignored, and only resurfaced more than fifty years later in the composite text Somatographia Anthropine. Published in I634, this text took a far more confident stance on phantom pain:

it is ordinary for the Patient, long after the member is cut off to imagine he yet hath it, and that he feeles paine in it. Now you must know that this is not altogether without cause. For the nerve or sinew which is cut in sunder, contracts it selfe towards his originall, and that contraction induces a paine much like a convulsion. For as Galen writeth in his booke, De motu musculorum, the proper action of a nerve and a muscle is contraction. Their tension is not so much an action as a motion. Wherefore you may ease that convulsive paine, by annointing the ridge of the backe, and the whole member also, with this following Liniment. ${ }^{\text {II }}$

The language in which these authors proffer a cure suggests that they too are not immune to the hypnotic effects of the phantom limb, talking of anointing the 'whole member' despite the fact that it is the 'unwholeness' of the member which generates the ailment in the first place. Gone, however, is the Workes' emphasis on the parallel apprehensions of the viewer/reader and the patient, along with its admission of PLP's strangeness. Where Paré's account is awestruck, that of Somatographia Anthropine

Io 'Prodigious, Adj. (and Int.) and Adv.', in OED Online (Oxford University Press), accessed I 3 December 2019, www.oed.com/view/Entry/I 5 I 95 I.

I Alexander Read, Somatographia Anthropine, or, a Description of the Body of Man. With the Practise of Chirurgery, and the Use of Three and Fifty Instruments, 2nd edition (London: printed by Thomas Cotes, and sold by Michael Sparke, I634), p. I I 4. First published in I6I6, this text was designed as an octavo-sized companion volume to Helkiah Crooke's anatomical treatise Mikrokosmographia: a Description of the Body of Man (a text commissioned by the printer William Jaggard in I6I5). Somatographia contains illustrations from Mikrokosmographia, some of which are altered. It has a preface by Alexander Read, and is usually listed as authored by Read, sometimes by Jaggard or Crooke. The most comprehensive explanation of this relationship I have found is Jillian Faith Linster, 'Books, Bodies, and the "Great Labor" of Helkiah Crooke's Mikrokosmographia,' Ph.D. (University of Iowa, 20I7), pp. 43-73. See also Lauren Kassell, 'Medical Understandings of the Body', in The Routledge History of Sex and the Body, ed. Kate Fisher and Sarah Toulalan (Abingdon: Routledge, 2013), pp. 57-74. 
is remarkable for its coolness, accepting as entirely natural and 'ordinary' a bodily event without any perceptible cause. ${ }^{\mathrm{I2}}$ Moreover, the sufferer of phantom pain is no longer united with the surgeon in perplexity at this 'deceitful' sensation. It is the patient who 'imagine[s]' that he 'yet hath' his amputated limb, and that it causes him pain. By contrast, for the medical professional, the phantom limb is both entirely explicable and eminently curable.

What changed between the Workes' account of 'wondrous strange' phantom pains and Somatographia Anthropine's description of the same phenomenon as 'ordinary'? Why was the nerve spasm theory advanced in Ten Bookes omitted from English translations of Paré, and then picked up several decades later? Part of the shift clearly involves the distancing of the medical practitioner from their patient, as part of a teleology of professionalisation among surgeons. In addition, however, the explanation offered by Ten Bookes, and later by Somatographia Anthropine, was engaged with theories about pain which became popular in England during the first half of the seventeenth century. Early seventeenth-century philosophers and physicians became increasingly focussed on sensation as an area for investigation. ${ }^{13}$ Bolstered by Pierre Gassendi's revival of atomism in France, many came to regard those sensations as produced and relayed, in some hydraulic fashion, by the nerves and spinal cord. ${ }^{I 4}$ As Darren Wagner describes

Among the contending theories, that of a nervous fluid coursing through a minuscule tubal structure of nerves gained the most credence. Publications by individuals such as René Descartes (I596-1650), William Harvey (I578-1657), Renier de Graaf (I64I-I673), Thomas Bartholin (I6I6-I680), Walter Charleton (I6I9-I707) and especially Thomas Willis ( $162 \mathrm{I}-\mathrm{I} 675$ ) advanced theories and principles about that nervous fluid, the animal spirits ... Animal spirits were see as a protean and fluid substance, extremely subtle, easily agitated, highly rarefied, fine and thin, lying just beyond the scope of visual observation. Produced in the brain and

${ }^{12}$ In this respect it is odd that more surgical texts do not mention phantom limb pain, particularly as modern research estimates that up to 80 per cent of amputees will experience the sensation, usually soon after surgery (Laxmaiah Manchikanti, Vijay Singh, and Mark V. Boswell, 'Phantom Pain Syndromes', in Pain Management, ed. Steven D. Waldman (Philadelphia: W. B. Saunders, 2007), pp. 304-I 5, https://doi.org/I0.I0I6/B978-0-72I6-0334-6.50032-7). However, at least some of this reticence may be explained by the fact that most surgeons were not involved in long-term aftercare for their patients, and that a much smaller proportion of amputees survived their operation to be able to report such sensations.

${ }^{13}$ Sydney Ochs, A History of Nerve Functions: From Animal Spirits to Molecular Mechanisms (Cambridge: Cambridge University Press, 2004), pp. 63-107.

${ }^{14}$ Ibid., p. 63. 
circulated via nerves, they seemed to move 'quicker than the twinkling of an Eye'. In function, they conveyed sensation, desire and motion. This ethereal fluid bridged the gap between the physical and the metaphysical, the body and the soul. ${ }^{\mathrm{IS}}$

While 'animal spirits' had long been a part of the lexicon for describing sensation, they were increasingly situated within theories of nerve vibration and tension. Matthew Cobb notes that 'Through a precise mechanical analogy, the original vague vitalism was transformed into a modern mechanistic conception. ' ${ }^{\text {I6 }}$ Scholars of various stripes were growing used to the notion that feeling had some material basis, though that basis might be mysterious and ill-understood. In so doing, they became increasingly interested in what phantom limbs could reveal about the nature of pain.

\section{Descartes and Phantom Pain}

Appropriately, the most famous figure in the project to understand sensation was also the man who had most to say about the phantom limb phenomenon. In a handful of passages from across his philosophical works, René Descartes established a way of thinking about phantom limb pain that lasted for well over a century. For its part, PLP furnished Descartes with a test case that shaped his ideas about perception and sensation, and exposed vulnerabilities in the dualist model. His interest in this topic began relatively early in his philosophical career. In a I 637 letter addressed to 'Plempius', but intended for the Belgian theologian Libert Froidmont, Descartes expresses his fascination with phantom limbs and the philosophical usefulness he finds in this phenomenon:

He [Froidmont] expresses surprise that on page 30 I recognize no sensation save that which takes place in the brain. On this point I hope that all doctors and surgeons will help me to persuade him; for they know that those whose limbs have recently been amputated often think they still feel pain in the parts they no longer possess. I once knew a girl who had a serious wound in her hands and had her whole arm amputated because of a creeping gangrene. Whenever the surgeon approached her they blindfolded her eyes so that she would be more tractable, and the place where her arm

is Darren N. Wagner, 'Body, Mind and Spirits: the Physiology of Sexuality in the Culture of Sensibility', Journal for Eighteenth-Century Studies 39:3 (2016): 337, https://doi.org/IO.IIII/ I754-0208.12336.

${ }^{16}$ Matthew Cobb, 'Exorcizing the Animal Spirits: Jan Swammerdam on Nerve Function', National Review of Neuroscience 3:5 (2002): 397, https://doi.org/I0.I038/nrn806. On animal spirits and mechanistic models, see also Julian Jaynes, 'The Problem of Animate Motion in the Seventeenth Century', Journal of the History of Ideas 3 I:2 (1970): 219-34, https://doi.org/I0.2307/2708546. 
had been was so covered with bandages that for some weeks she did not know she had lost it. Meanwhile she complained of feeling various pains in her fingers, wrist, and forearm; and this was obviously due to the condition of the nerves in her arm which formerly led from her brain to those parts of her body. This would certainly not have happened if the feeling or, as he says, sensation of pain occurred outside the brain. ${ }^{17}$

The explanation Descartes gives for phantom pain here concurs broadly with that given in Somatographia Anthropine: pain arises from the irritation of the severed nerves which previously led to the amputated part. Importantly, the fact that Descartes uses PLP as evidence to bolster the claims of his own natural philosophical writings shows how interwoven the philosopher's concept of pain was with his concept of vision. Both, as I will demonstrate, rested on the fundamental belief that one could not take the veracity of the object world for granted - could not, in fact, assume certain knowledge of anything beyond cogito ergo sum. The text to which Descartes refers above is presumably his Discourse on Method, published in the same year. In the sixth discourse of that text, 'Of Vision', Descartes explains that while the eye is the instrument of vision, it is not the eye that perceives objects:

Now although this picture [of the physical world] in being so transmitted into our head, always retains some resemblance to the objects from which it proceeds, nevertheless, as I have already shown, we must not hold that it is by means of this resemblance that the picture causes us to perceive the objects as if there were yet other eyes in our brain with which we could apprehend it; but rather, that it is the movements of which the picture is composed which, acting immediately on our mind inasmuch as it is united to our body, are so established by nature as to make it have such perceptions. ${ }^{18}$

Much as in the case of pain sensations, Descartes believed that stimulation of the nerves on the retina provoked a movement of animal spirits, which would then pass into a ventricle of the brain and on to the pineal gland, which caused the perception of a sighted object. As Ochs explains,

The soul, the rational cognitive thinking soul ... expresses its actions through the pineal gland. Sensory inputs passing by means of animal spirits

${ }^{17}$ Extract from a letter to Plempius for Fromondus [Libert Froidmont, Belgian theologian and scientist], 3 October 1637, in René Descartes, The Philosophical Writing of Descartes, Volume III: The Correspondence, trans. John Cottingham et al. (Cambridge: Cambridge University Press, I99I), p. 64 .

${ }^{18}$ René Descartes, Discourse on Method, Optics, Geometry, and Meteorology (I637), trans. Paul J. Olscamp (Indianapolis: Hackett, 200I), p. Iо I. 
in nerve tubules project them onto the pineal gland. There, sensations are perceived and animal spirits are directed by the soul into the proper nerve tubules to effect muscle movements. ${ }^{\text {I9 }}$

Descartes' thoughts on vision were not only a matter for physiologists. As the hot topic of seventeenth-century natural philosophy, 'the problematics of vision' were, in Stuart Clark's words, '[t] he agenda for all really serious thought'. ${ }^{20}$ Central to Cartesian wisdom on the issue was the principle of 'non-resemblance' between objects and visual perceptions. Though material things possessed the properties of extension (i.e. taking up space in the world) and geometry (shape, size, and motion), other qualities, such as colour, existed in the eye of the beholder. A group of onlookers might agree, for instance, that an object was red, but the perception of 'redness' was generated individually in each person's mind, rather than inhering in the viewed object. Clark explains:

Sensing is occurring [in the eye], but not perception - not 'seeing' - the functioning of a machine (which, by definition, is without judgement), not the understanding of a thinking mind: '[I]t is the soul which sees', declared Descartes famously, 'and not the eye; and it does not see directly, but only by means of the brain. ${ }^{21}$

The preceding chapters have shown that early modern people conceived of embodiment in varied and often fluctuating ways: the body could be imagined as entirely entwined with one's mental subjectivity, or as utterly divorced from it. Feelings of every kind were felt to be generated in a complex relationship between the passions, intellect, and soul, such that raw affect and mediated emotion were in practice virtually impossible to separate. ${ }^{22}$ Descartes' theory of non-resemblance appeared to offer clarity in these murky waters. Non-resemblance meant that there was no innate correspondence between outside stimuli and cognitive experience. Impulses provoked in the nerves by exogenous stimuli had no affective meaning in themselves, and to experience pain 'in' one's finger was as illusory as experiencing dread 'in' the pit of one's stomach.

19 Ochs, $A$ History of Nerve Functions, p. 64.

${ }^{20}$ Stuart Clark, Vanities of the Eye: Vision in Early Modern European Culture (Oxford: Oxford University Press, 2007), p. 332.

2 I Ibid., p. 342.

22 'Affect' is used here in the way suggested by Jan Plamper, to signify 'nonconscious, nonsignified, inchoate states'. 'Jan Plamper On the History of Emotions | The History of Emotions Blog', accessed 5 September 20I7, https://emotionsblog.history.qmul.ac.uk/2017/og/jan-plamper-onthe-history-of-emotions/. 
Because they generated a false picture of the body, phantom limbs seemed to exemplify non-resemblance, and so Descartes returned to this phenomenon throughout his philosophical career. In 1644, for instance, his Principles mentioned again the case of the girl with the phantom hand:

She had various pains, sometimes in one of the fingers of the hand which was cut off, and sometimes in another. This could clearly only happen because the nerves which previously had been carried all the way from the brain to the hand, and afterwards terminated in the arm near the elbow, were there affected in the same way as it was their function to be stimulated for the purpose of impressing on the mind residing in the brain the sensation of pain in this and that finger. ${ }^{23}$

In this case, phantom limb pain was presented as proving the nonresemblance of pain sensations specifically. Descartes explained: 'the soul feels those things that affect the body not in so far as it is in each member of the body, but only in so far as it is in the brain'. ${ }^{24}$ Thus it was possible that in rare cases, '[w]e sometimes feel pain as though it were in certain of our members, and yet its cause is not in those members where it is felt, but in others through which the nerves pass that extend to the brain from the parts where the pain is felt'. ${ }^{25}$ Phantom limb pain was thus explained by, and simultaneously taken as evidence for, the 'bell-cord' theory of pain which Descartes famously outlined in his On Man (written I630-3 but published posthumously in I662). Aided by the illustration shown in Figure 6.I, Descartes argued:

if the fire $\mathrm{A}$ is close to the foot $\mathrm{B}$, the small particles of fire, which as you know move very swiftly, are able to move as well the part of the skin which they touch on the foot. In this way, by pulling at the little thread cc, which you see attached there, they at the same instant open e, which is the entry for the pore $\mathrm{d}$, which is where this small thread terminates; just as, by pulling one end of a cord, you ring a bell which hangs at the other end ... Now when the entry of the pore, or the little tube, de, has thus been opened, the animal spirits flow into it from the cavity F, and through it they are carried partly into the muscles which serve to pull the foot back from the fire, partly into those which serve to turn the eyes and the head to look at it, and partly into those which serve to move the hands forward and to turn the whole body for its defense. ${ }^{26}$

${ }^{23}$ René Descartes, 'Principles of Philosophy', in The Philosophical Works of Descartes, trans. Elizabeth S. Haldane and G. R. T. Ross, vol. I (of 2) (Cambridge: Cambridge University Press, I 91 2), pp. 293-4.

${ }^{24}$ Ibid., p. $293 . \quad 25$ Ibid., pp. 294.

${ }^{26}$ René Descartes, Treatise of Man (I 662), trans. Thomas Steele Hall (Amherst: Prometheus Books, 2003), pp. 33-4. 


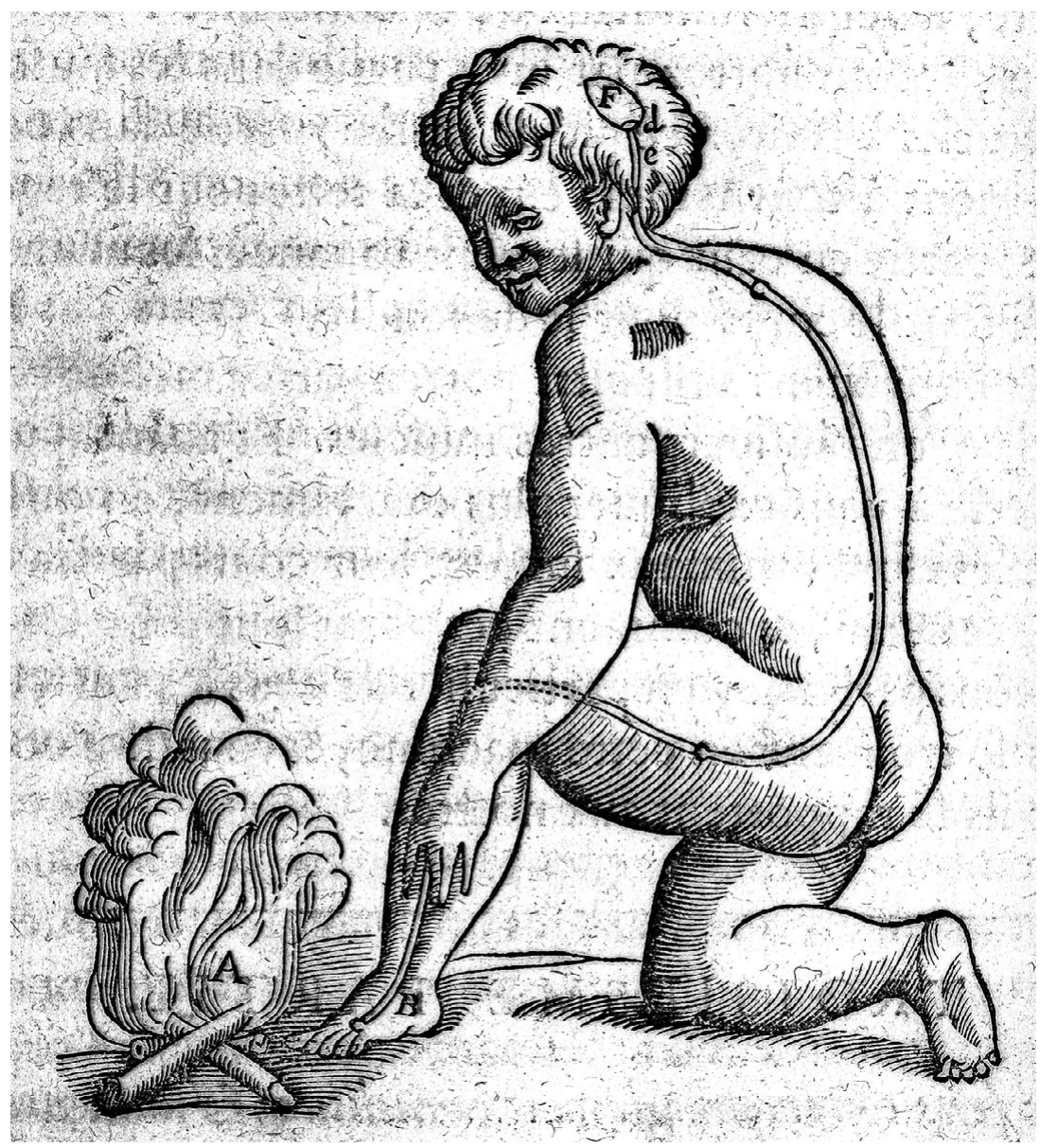

Figure 6. I Descartes, 'The Path of Burning Pain. Comme elle est incitee par les objets exterieurs a se mouvoir en plusiers manieres'.

Credit: Wellcome Collection. CC BY

The bell-cord theory proved immensely appealing to generations of physicians. ${ }^{27}$ In particular, its presentation of pain as reliant on the transmission of some substance through the nerves seemed to anticipate the biochemical model of nociception which emerged some

27 Joanna Bourke discusses the long and varied afterlife of Descartes' model in her The Story of Pain: From Prayer to Painkillers (Oxford: Oxford University Press, 2014), especially pp. I2-I 3. 
250 years later. ${ }^{28}$ Furthermore, the wide reach of Descartes' work ensured that both the principle of non-resemblance and the phantom pain phenomenon used to illustrate that model influenced writers on a surprisingly broad range of topics. These writers included Antoine de Courtin, the author of $A$ Treatise of Jealousie ( $\mathrm{I} 684$ ). De Courtin speculated that jealousy might have a physiological basis - something which he argued was possible because of the capacity of the senses to deceive the understanding. This capacity relied in turn on a neurocentric model of sensation, in which de Courtin clearly drew from Descartes' works:

Now as it is this Organ [the brain] that receives the Impressions or the Species that are sent thither by the External Organs or Senses, it must by Consequence be in this Place, and in the Brain that Sensation or the Perception which we have of things is perform'd, and not at all in the External Senses themselves, or any other part of the Body. For although the outward Senses are as the Instruments, that the Imagination makes use of, for the Reception of the Species of Sensible Objects; although they are as the ports of the Soul, by which the Species do enter; yet the Objects are Imprinted, and as it were Limned in these Organs (for we find by Experience that we see by the Eyes, hear with the Ears, and that the Hand or Foot gives us the Sense of Pain) nevertheless without all doubt, we can have no Sensation, no Perception or discerning, if the Species or Impressions have not passage to the Principal Seat of the Imagination or Common Sense. We have experience thereof in this, that if we [are] very attentive to any thing, we perceive not the Pain of any hurt received, nor do we see the things that are before our Eyes; as it happens to these that are Apoplectick, they perceive not at all when they are pricked, no nor when they are Wounded, which must proceed from hence, that the Organ of the Imagination ceasing its Action, it receives no Impression, and consequently it produces no Sensation; And what is more, these that have, for Example, their hand Amputated, do complain of great Pains in that very Hand, that was cut off. ${ }^{29}$

De Courtin's use of phantom limbs as an example in a text entirely unrelated to that subject shows that, following Descartes, this

${ }^{28}$ S. Scott Graham, The Politics of Pain Medicine: a Rhetorical-Ontological Inquiry (Chicago: University of Chicago Press, 2015), pp. 49-50.

${ }^{29}$ Antoine de Courtin, A Treatise of Jealousie, or, Means to Preserve Peace in Marriage Wherein Is Treated of I. The Nature and Effects of Jealousie, Which for the Most Part Is the Fatal Cause of Discontents between Man and Wife, II. And Because Jealousy Is a Passion, It's Therefore Occasionally Discoursed of Passions in General, Giving and Exact Idea of the Production of Passions, and of the Oeconomie of the Body so Far as It Relates Thereunto. III. The Reciprocal Duties of Man and Wife, with Infallable Means to Preserve Peace in the Family, by Avoiding Dissentions That May Arise from Jealousie, or Any Other Cause Whatever (London: printed for W. Freeman, I684), pp. I4-I 5. 
phenomenon acquired scholastic interest as a set-piece, a physical anomaly meant to prove the rule that inward perceptions did not always match up with outward realities. De Courtin's language here bespeaks his interest in the subject of perception in general; the encroachment of 'species' on the nervous system was an Aristotelian idea, rooted in the notion that objects in the world consisted of both matter and form ('species'). Though the neurocentric model de Courtin embraces jettisoned the idea of 'species', this term clearly remained in the minds of omnivorous readers. At the same time, however, de Courtin's reading of the bell-cord theory, understood through the prism of phantom limb pain, downplayed the role of the body and the sense organs in perception by casting them as mere 'instruments' for the use of a subjective self which was apparently located elsewhere. In de Courtin's interpretation, both affect and emotions including jealousy - are reoriented from visceral to purely cognitive, a departure from the humoral schema in which melancholy, anger and so forth were conditions of both body and soul. 'Sensation', argued de Courtin, is perform'd in the imagination, and not in the External Organs, or parts of the Body, whereon the first Impression is made, so likewise the Passions are not form'd in the Heart; as some believe, but in the same Imagination also. ${ }^{.30}$ Notably, in this formulation, 'External Organs' include not only those organs, such as the skin, which interface with outside stimuli, but any organ which is not the mind.

De Courtin's passage was clearly meant to be an endorsement of Descartes' non-resemblance theory, and it is notable that he saw phantom limbs as among the most pertinent proofs of that theory. At the same time, however, some of the examples which de Courtin cited as evidence of sensory unreliability were clearly problematic. Apoplexies and other mental disorders were believed to be caused by disordered passions or animal spirits, but it was by no means clear how the material substance of those spirits acted on the immaterial mind to cause symptoms such as insensibility. Descartes' explanation for phantom limb pain was that since the mind was connected to the body at a single point (the brain, specifically the pineal gland), it was possible that motions of the pineal gland might be effected from time to time by stimuli which did not accord with what was typical (nerve impulses that did not 'really' come from a limb, for instance). This provoked both neurophysiological and epistemological questions. Physiologically, phantom limb pain was described as seeming to come from one point in a nervous pathway when in fact it derived from

30 Ibid., p. I7. 
another. However, as Tommy Lott has noted, it was unclear how Descartes supposed that nerve impulses conveyed information about the location of a pain signal at all. ${ }^{3 \mathrm{I}} \mathrm{He}$ seems to have believed that location was somehow intrinsic in the response that stimulation of the neural pathways produced in the brain, though exactly how this occurred was ambiguous.

More troubling for Descartes, and for many of his critics, was the epistemological issue of human reason versus sensory unreliability. The fact of non-resemblance meant that the body could deceive the person 'inside', and, as Descartes noted, this worrying potential was epitomised by phantom limb pain:

I have learned from some persons whose arms or legs have been cut off, that they sometimes seemed to feel pain in the part which had been amputated, which made me think that I could not be quite certain that it was a certain member which pained me, even although I felt pain in it. ${ }^{32}$

It was thus necessary to doubt not only the existence of outside objects, but even the nature of pain in one's own body. Despite this observation, Descartes argued that God had paired sensations with effects on the pineal gland in the way that worked in the majority of cases, and could not have done otherwise given the nature of the connection between mind and body. ${ }^{33}$ 'It is quite clear,' he argued, 'that, notwithstanding the supreme goodness of God, the nature of man, inasmuch as it is composed of mind and body, cannot be otherwise than sometimes a source of deception. ${ }^{34}$ However, in the rare case where a nerve 'message' was deceptive - as in phantom pain - a human being's God-given rationality was capable of sorting out the confusion, since one would look at one's stump, remember the amputation, and be corrected. This accorded with a central tenet of Descartes' world-view - the notion that a benevolent God would not allow humans to be deceived, and that one could therefore (with the help of reason) trust in the reality of the perceived world. Wilson notes that

In considering God's benevolence in the Fourth Meditation Descartes maintained that such a benign creator could not have given him a faculty

${ }^{31}$ Tommy L. Lott, 'Descartes on Phantom Limbs', Mind and Language I:3 (1986): 248-9, https://doi .org/IO.IIII/j.I 468-00I7.I986.tboor03.x.

32 René Descartes, 'Meditation VI', in The Philosophical Works of Descartes, vol. I (of 2), trans. Elizabeth S. Haldane and G. R. T. Ross (Cambridge: Cambridge University Press, 1912), p. 189 .

33 Sarah Patterson, 'Descartes on the Errors of the Senses', Royal Institute of Philosophy Supplement 78 (2016): 73-108.

${ }^{34}$ Descartes, 'Meditation VI', p. 198. 
that would lead him into error if he used it rightly. The partial vindication of the senses, however, is made to rest on a different principle: that God would not allow me to fall into any error which $\mathrm{He}$ did not give me the power to correct. This principle is needed to affirm the existence of material objects, since Descartes apparently wants to hold back from saying their existence is clearly and distinctly perceived. ${ }^{35}$

While this approach seemed to reconcile bodily deception and divine design, it fell short as an explanation for phantom limb pain, in which 'the power to correct' sensory anomaly was conspicuously absent. Looking at Descartes' example in the context of contemporary medical texts, we can see how the 'faulty senses corrected by reason' explanation elides the particular 'strangeness' of phantom limbs which had long been identified by Paré and Read. These authors recognised that knowing intellectually that a phantom limb is not real does not stop the 'limb' from hurting; rather, it is the cognitive dissonance between what is seen and what is felt that makes phantom limb pain so distressing.

Whether Descartes recognised that phantom limbs were immune to reason in this way is debatable. As was the case for many of this book's sources, he seemingly regarded people with disabilities - in this case, phantom limb pain sufferers - as people to think with, rather than to talk to. Nonetheless, it is clear that the experience and the theory of pain were hard to reconcile, even for avowed adherents of dualism. This was demonstrably the case for the eighteenth-century scientist William Porterfield (c. I696-I77I). Porterfield was an eminent Scottish physician, who shared with Descartes, Thomas Willis, Hobbes, and others a particular interest in the mechanics of vision. ${ }^{36} \mathrm{He}$ was also the first person to publish an autobiographical account of phantom limb pain, as a part of his Treatise on the Eye (1759). Just as Descartes had done more than a century earlier, he marshalled the phantom limb in service of his understanding of sensory perception, and his account is worth citing at length:

It is ... evident, that, did the Mind perceive Pictures in the Retina, it behoved to be there present: And for the same Reason, did it perceive in the other Organs of Sense, it behoved to be there present: And for the same Reason, did it perceive in the other Organs of Sense, it behoved also to be present to all the parts of the Body; because the Sense of Feeling is diffused thro' all the Body: Nay in some Cases it behoved to be extended beyond the

${ }^{35}$ Margaret Dauler Wilson, Descartes (Abingdon: Routledge and K. Paul, 1978), p. 202.

${ }^{36}$ Nicholas J. Wade, 'The Vision of William Porterfield', in Brain, Mind and Medicine: Essays in Eighteenth-Century Neuroscience, ed. Harry Whitaker, C. U. M. Smith, and Stanley Finger (Leiden: Springer, 2007), pp. I63-77. 
Body itself, as in the Case of Amputations, where the Person, after the Loss of his Limb, has the same Perception of Pain, Itching, \&c. as before, and feels them as if they were in some Part of his Limb, tho' it had long ago been amputated, and removed from that Place where the Mind places the Sensation. Having had this Misfortune myself, I can the better vouch the Truth of this Fact from my own Experience; for I sometimes still feel Pains and Itching, as if in my Toes, Heel or Ancle, \&c. tho' it be several Years since my Leg was taken off. Nay, these Itchings have sometimes been so strong and lively, that, in spite of all my Reason and Philosophy, I could scarce forbear attempting to scratch the Part, tho' I well knew there was nothing there in the Place where I felt the Itching. And however strange this may appear to some, it is nevertheless no way miraculous or extraordinary, but very agreeable to the usual Course and Tenor of Nature; for, tho' all our Sensations are Passions or Perceptions produced in the Mind itself, yet the Mind never considers them as such, but, by an irresistible Law of our Nature, it is always made to refer them to something external, and at a Distance from the Mind; for it always considers them as belonging either to the Object, the Organs, or both, but never as belonging to the Mind itself, in which they truly are; and therefore, when the nervous Fibres in the Stump are affected in the same manner as they used to be by Objects acting on their Extremities in the Toes, Heel or Ancle, the same Notice or Information must be carried to the Mind, and the Mind must have the same Sensation, and form the same Judgment concerning it, viz. that it is at a Distance from it, as if in the Toes, Heel or Ancle, tho' these have long ago been taken off and removed from that Place where the Mind places the Sensation.

If this should prove hard to be conceived, It may be illustrated by what happens in the Sensation of Colours; for tho' the Colours we perceive are present with the Mind, and in the Sensorium, yet we judge them at a Distance from us, and in the Objects we look at; and it is not more difficult to conceive how Pain may be felt at a Distance from us, than how Colours are seen at a Distance from us. ${ }^{37}$

As Nicholas Wade recognises, Porterfield 'displayed considerable sophistication in the analysis of his phantom limb, by associating the projective features of the experience with other aspects of perception' ${ }^{38}$ Porterfield's treatment of his own pain as merely a useful example for illustrating his theory of vision reflects both the intellectual idealism of the Enlightenment and the subordination of the physical to the mental which is implied in the Cartesian world-view. Porterfield developed Descartes'

37 William Porterfield, A Treatise on the Eye, the Manner and Phenomena of Vision, vol. I (of 2) (Edinburgh: printed for A. Miller at London, and for G. Hamilton and J. Balfour at Edinburgh, I759), pp. 363-5.

38 Wade, 'The Vision of William Porterfield', p. I74. 
theory of optics by developing a much more detailed understanding of the anatomy of the eye, and by dwelling at greater length on the fact that objects perceived in the mind were nonetheless sensorially positioned as 'out' in the world. His reference to colour here also demonstrates his indebtedness to Newtonian colour theory, which posited that the experience of colour was subjective, rather than intrinsic in rays of light. ${ }^{39}$ Of particular interest to Porterfield was the spatiality of perception: the fact of sensations seeming to be produced 'at a distance' from the mind, which was as much a product of his work on physiology as of his philosophy. ${ }^{40}$ Throughout Porterfield's investigations into perceptual theory, his ideological debt to Cartesianism is evident:

Now, as Objects seen by Reflection or Refraction appear and are seen, not in their true Place, but in some other Place from which they are absent, and that because the Rays fall upon the Eyes, and make a Picture on their Bottom, in the very same Manner as if they had come from the Object really placed there, without the Interposition of the Glass; so, when the Impression made upon the nervous Fibres of the Stump is the same as if it had come from an Object acting on their Extremities, the Sensation must also be the same, and the Mind, by forming the same Judgment concerning it, must feel it as in the Toes, Heel, or Ancle, \&c. in which those nervous Fibres terminated before the Leg was taken off. ${ }^{4 \mathrm{I}}$

Here Porterfield seems to be referring specifically to Descartes' example of the stick placed in water, which appears bent but is, by reason, understood merely to seem that way because of the effect of refraction. ${ }^{42}$ He does so in service of a theory of perception which identifies both phantom limb pain and optical illusions as evidence for sensory non-resemblance. The use of phantom limbs to support the notion that sensation and perception were localised in the brain rather than the body was, as Wade notes, also taken up in the late eighteenth century by Charles Bell and Johannes Müller. ${ }^{43}$ Indeed, in her work on pain, Roselyne Rey argues that a dualist

39 Ibid., p. I74.

40 Porterfield was the first to describe the 'accommodation' of the eye, whereby structures such as the lens and pupil alter in response to focussing on a near or distant object. 'William Porterfield | Portraits of European Neuroscientists', accessed 7 August 2017, http://neuroportraits.eu/portrait/ william-porterfield.

4I Porterfield, A Treatise on the Eye, vol. I, pp. 366-7.

42 Bruce Stansfield Eastwood, 'Descartes on Refraction: Scientific versus Rhetorical Method', Isis 75:3 (I984): 48I-502, https://doi.org/I0.I086/353568.

43 Of note, phantom penises were also reported by several late eighteenth-century physicians, including John Hunter. Nicholas J. Wade and Stanley Finger, 'Phantom Penis: Historical Dimensions', Journal of the History of the Neurosciences I9:4 (2010): 299-3 I 2, https://doi.org/IO .1080/09647040903363006). 
explanation of phantom limb syndrome was conceptually necessary to mechanistic investigations of the body and brain:

It was necessary to explain mental phenomena such as the hallucinations of madness or the pains of amputees, which were lumped together since in neither case could one blame an external cause that would have been liable to affect the nerves. In so doing, the 'mechanist' physicians conceded that 'one cause, whatever it might be, would produce the same change in the brain as would have happened had there been a nerve fibre ... so disposed that its dissolution could have been a consequence. ${ }^{.44}$

The most interesting part of Porterfield's account, however, may be less his rationalisation of his pains than his admission that 'I could scarce forbear attempting to scratch the Part, tho' I well knew there was nothing there'. In Porterfield's frustration with his own response to the painful 'part', one sees another irony of phantom limb pain. As Descartes recognised, pain was a profoundly intimate phenomenon, seemingly more immediate than any other. Notwithstanding this fact, pain was also, as phenomenologists and historians of emotion have shown, socially and culturally mediated. ${ }^{45}$ While one might not be able to feel another's pain directly (though as Chapter 3 has shown, the limits of sympathy were up for debate), one can at least liken it to similar feelings from one's own experience, or can look at a person's injury and surmise its painfulness. In the case of phantom limb pain, this possibility is diminished. The phantom limb's lack of objective existence also shuts down the intersubjective networks within which bodily experience is partly lived out. ${ }^{46}$ For Porterfield, the nature of his pain seems to have been particularly galling because of his status as a man of science, who could not resist scratching his missing leg 'in spite of all my Reason and Philosophy'; this man dedicated to mapping the human body found that his own proprioceptive

${ }^{44}$ Roselyne Rey, The History of Pain, trans. Louise Elliot Wallace, J. A. Cadden, and S. W. Cadden (Cambridge: Harvard University Press, I995), pp. I03-4.

45 The topic of pain has been prominent in recent scholarship of the early modern period, with all analyses recognising the cultural specificity and sociality of pain: see Louise Hide, Joanna Bourke, and Carmen Mangion, 'Perspectives on Pain: Introduction', I9: Interdisciplinary Studies in the Long Nineteenth Century, I5 (2012), https://doi.org/I0.I6995/ntn.663; Bourke, The Story of Pain; Jonathan Sawday, "II Feel Your Pain”: Some Reflections on the (Literary) Perception of Pain', in The Hurt(Ful) Body: Performing and Beholding Pain, I600-I800, ed. Tomas Macsotay, Cornelis Van der Haven, and Karl Vanhaesebrouck (Manchester: Manchester University Press, 20I7) pp. 97-I I4; Jan Frans van Dijkhuizen and Karl Enenkel, The Sense of Suffering: Constructions of Physical Pain in Early Modern Culture (Leiden: Brill, 2009); Michael C. Schoenfeldt, 'Shakespearean Pain', in Shakespearean Sensations: Experiencing Literature in Early Modern England, ed. Katharine A. Craik and Tanya Pollard (Cambridge: Cambridge University Press, 2013), pp. I9I-207.

${ }^{46}$ See Tilmouth, 'Passion and Intersubjectivity in Early Modern Literature', pp. 24-3 I. 
powers had failed him. Indeed, his use of this experience to explicate his scientific theory of vision may have been in part an attempt to exercise control over his uncontrollable phantom by bringing it into line with his vision of himself as a rational creature. Phantom limbs thus exemplified the resistance of the body to sociability and to intellectualism, its resistance to being understood 'from the outside'. As Betty Bayer eloquently suggests,

quickened by historical struggles and negotiations around doubt, controversy, and skepticism troubling the subject of Enlightenment science, phantoms open science onto the terrain of subjectivism, fears, and desires (secret and known). To inquire into the transversals of spirits animating relations between humans and nonhumans, bodies and machines in the production of scientific knowledge is to raise the specter of divine truth, to query those ways in which the imaginary and the rational coextend and dwell in one another. ${ }^{47}$

\section{The Hard Problem}

Offering up bodily feeling unbounded by the body itself, phantom limbs proffered a disconcerting excess of subjectivity, whereby the perceived limits of the body failed to contain the feeling 'self. This de-segregation of 'the imaginary and the rational', or of self-subject and body-object, also presented Cartesian dualism with its most serious stumbling block. In his wider discussion of sensation, Porterfield found it necessary to refute the notion of the soul as extended throughout the body (a notion explored in Chapter 5 of this book). Such an idea, he insisted, implied that the soul had different capabilities in the different areas in which it existed - that of seeing in the eyes, hearing in the ears, and so on. Though Porterfield scoffed at this notion, however, it exposed a weakness in the dualist model which troubled even its most devoted proponents: the question of how, exactly, the body and soul could interact. This dilemma - the so-called 'hard problem' - had been raised with Descartes many times. Most notably, it was a central theme of his extensive correspondence with Princess Elisabeth of Bohemia (I618-80), the grand-daughter of James I. As Lisa Shapiro has observed, in the pair's correspondence Elisabeth repeatedly presses Descartes on the issue of how the immaterial and the

47 Betty M. Bayer, 'Between Apparatuses and Apparitions: Phantoms of the Laboratory', in Reconstructing the Psychological Subject: Bodies, Practices, and Technologies, ed. John Shotter and Betty M. Bayer (London: Sage, I998), p. I88. 
material (the mind and the animal spirits) can influence one another, and in particular, why it should be the case that a physical indisposition can affect the mind. In June I643, for example, she writes:

I admit that it would be easier for me to concede matter and extension to the soul than to concede the capacity to move a body and to be moved by it to an immaterial thing. For, if the first is achieved through information, it would be necessary that the spirits, which cause the movements, were intelligent, a capacity you accord to nothing corporeal. And even though ... you show the possibility of the second, it is altogether very difficult to understand that a soul, as you have described it, after having had the faculty and the custom of reasoning well, can lose all of this by some vapors, and that, being able to subsist without the body, and having nothing in common with it, the soul is still so governed by it. ${ }^{48}$

Elisabeth's attention was drawn to this issue once again after she wrote to the philosopher complaining of a cough. He, considering the ailment to be caused by stress, advised her to meditate upon her soul and her own strength as a means to wellness. His response provoked another question from Elisabeth. If mind and body were truly separate, she wondered, how could mental attitude affect physical wellbeing?

I do not yet know how to rid myself of the doubt that one can arrive at the true happiness of which you speak without the assistance of that which does not depend absolutely on the will. For there are diseases that destroy altogether the power of reasoning and by consequence that of enjoying a satisfaction of reason. There are others that diminish the force of reason and prevent one from following the maxims that good sense would have forged and that make the most moderate man subject to being carried away by his passion. ${ }^{49}$

Judging by her correspondence, Elisabeth was never truly satisfied with Descartes' responses to her questions, though she politely framed them as the products of her own 'stupidity'. ${ }^{\circ}$ As Shapiro argues, Descartes

${ }^{48}$ Elisabeth of Bohemia, 'Elisabeth to Descartes [The Hague] Io June I643 (AT 3:683)', in Princess Elisabeth of Bohemia and René Descartes, The Correspondence between Princess Elisabeth of Bohemia and René Descartes, ed. Lisa Shapiro (Chicago: University of Chicago Press, 2007), pp. 67-9 (emphases added).

49 Elisabeth of Bohemia, 'Elisabeth to Descartes [The Hague] I6 August I645 (AT 2:268)', in The Correspondence between Princess Elisabeth of Bohemia and René Descartes, pp. I28-30.

so In fact, Elisabeth was a highly educated woman with extensive intellectual connections. In I66o she became abbess of the Lutheran convent at Herford, Germany, where she remained until her death in I680. Lisa Shapiro, 'Elisabeth, Princess of Bohemia', in The Stanford Encyclopedia of Philosophy, ed. Edward N. Zalta, Winter 2014 (Metaphysics Research Lab, Stanford University, 20I4), https:// plato.stanford.edu/archives/win2o I 4/entries/elisabeth-bohemia/. 
repeatedly seems to fudge the issue of body-mind interactionism in his replies to the princess, and Elisabeth appears eventually to have navigated her own way through this maze, finding a path that avoided 'the kind of substance dualism that Descartes appears to espouse'. ${ }^{\text {I }}$

These issues were also struggles for Descartes himself, whom Wilson characterises as having oscillated between two visions of the mind-body interaction. In the Meditations, Descartes proposed that pain 'in' a certain part of the body was felt as such only by God's ordinance. It so happened that the stimulation of the nerves in a particular area created a sensation in the mind as if it occurred in (for example) the foot. Wilson explains:

The mind must be said to perceive 'in the brain,' since if it perceived 'in the limbs,' for example, we should be able directly to distinguish cases of peripheral stimulation from cases of intermediate nervous disorder, and this we cannot do ... The prevailing tendency to ascribe pains to our feet and hands is said to be deluded for the reason that pains are after all sensations, and feet and hands are nothing but bits of res extensa, and assigning sensations to some bits of res extensa is just as intelligent as assigning them to any other bits - say to the chalk or the blackboard. ${ }^{52}$

This reading of sensation as a phenomenon of res cogita was that which proved influential on decades of writing about phantom limb pain. Yet, Descartes at points appeared to espouse a quite different idea of mindbody interaction. The theory of 'co-extension', as Wilson terms it, saw mind and body as 'in union' or 'intermixed'. In a famous passage from 'Meditation VI', Descartes cast the mind-body relationship as more than intellectual:

Nature also teaches me, by these sensations of pain, hunger, thirst and so on, that I am not merely present in my body as a sailor is present in a ship, but that I am very closely joined and, as it were, intermingled with it, so that I and the body form one thing. If this were not so, I, who am nothing but a thinking thing, would not feel pain when the body was hurt, but would perceive the damage by the pure intellect, just as a sailor perceives by sight if anything in his ship is broken. Similarly, when the body needs food or drink, I should have an explicit understanding of the fact, instead of having confused sensations of hunger and thirst. For these sensations of hunger,

${ }^{51}$ Lisa Shapiro, 'Princess Elizabeth and Descartes: the Union of Soul and Body and the Practice of Philosophy', British Journal for the History of Philosophy 7:3 (1999): 51 5, https://doi.org/10.1080/ 09608789908571042.

52 Wilson, Descartes, p. 209. 
thirst, pain and so on are nothing but confused modes of thinking which arise from the union, and as it were, intermingling of the mind with the body. ${ }^{53}$

Viewed in relation to phantom limb pain, this passage seems to recognise the problem identified above, that the mind does not rationalise all bodily experience. Hunger and thirst are experienced as 'confused sensations' rather than items of information. Phantom limbs resist rationalisation despite the fact that the sufferer knows them to be illusory.

Philosophers have pored over Descartes' writings on this topic, looking for an answer to the 'hard problem' which does not seem to be forthcoming. In light of the altered body, however, and in particular of phantom limb pain, the question takes on an interesting significance. Reading Descartes' varied interpretations of res extensa versus res cogita, Wilson comments that the latter seems to have no necessary relationship to the former, but only interacts with it as it is ordained by God that impulse X in the body should produce sensation $\mathrm{Y}$ in the mind. Therefore, she argues, 'It is, at best, hard to see how our unjustified tendency to ascribe experiences to parts of what we call our body could justify us in calling this thing our body. ${ }^{54}$ That is, if the relationship between impulse $\mathrm{X}$ and sensation $\mathrm{Y}$ is only incidental, God might as easily locate the pain which we experience 'in' our bodies 'in' other bodies - even animal or inanimate bodies. Seemingly this thought also occurred to Descartes, as he makes an effort in his writings to Elisabeth and elsewhere to explain how he believes the soul can be extended through the body in a non-corporeal sense (Elisabeth, like many of Descartes' readers, found the idea of noncorporeal extension illogical). In a series of letters to the Jesuit Denis Mesland in $1644-5$, Descartes explained that he conceived of selfhood as inhering in the combination of body and mind. Thus, the body could be called a divisible object, but the identity of the body of a particular person was an indivisible subject. The soul was the form of the body, and one could therefore claim to have the same body throughout one's life regardless of whether it was fat or thin, infant or elderly, or even whether it had all its original parts. In explanation, he returned to the altered body:

In that sense [a human body] ... can even be called indivisible, because if an arm or a leg of a man is amputated, we think that it is only in the first [object] sense of 'body' that this body is divided - we do not think that a man who has lost an arm or a leg is less a man than any other. ${ }^{55}$

53 Descartes, 'Meditation VI', p. I92. $\quad{ }^{54}$ Wilson, Descartes, p. 2 I 8 (emphasis added).

s5 René Descartes, 'Letter to Mesland, 9 February 1645', cited in Deborah Brown, 'The Sixth Meditation: Descartes and the Embodied Self, in The Cambridge Companion to Descartes' Meditations, edited by David Cunning (Cambridge: Cambridge University Press, 2014), p. 253. 
Descartes' definition of identity here is notably similar to Locke's definition of 'man'. In Locke's estimation, to be the man X involves having the body and mind of X. The principium individuationis which makes a tree a tree or a man a man, rather than (or as well as) a mere collection of particles, consists in its 'organisation of a common life'. Thus Locke, like Descartes, believed one could claim to look at the same man (or tree) as one had ten years previously, even if that entity contained none of the same material as it had at first view. ${ }^{56}$

Of course, Locke diverged radically from Descartes in that he distinguished between 'man', thus defined, and 'person'. Personhood, for Locke, implied a continued consciousness, such that one might legitimately claim that an amputated limb was a whole person, if personality and memories could be shown still to inhere in that organ. Conversely, what made a body one's own was the experience of sensation and perception related to that body. ${ }^{57}$ Locke writes, in his 1690 Essay Concerning Human Understanding.

That this is so, we have some kind of evidence in our very bodies, all whose particles, whilst vitally united to this same thinking conscious self, so that we feel when they are touched, and are affected by, and are conscious of good or harm that happens to them, are a part of our selves i.e. of our thinking conscious self. Thus the limbs of his body are to everyone a part of himself; he sympathizes and is concerned for them. Cut off an hand, and thereby separate it from that consciousness he had of its heat, cold, and other affections; and it is then no longer a part of that which is himself, any more than the remotest part of matter. ${ }^{58}$

Locke, despite having read and critiqued Descartes, did not make the connection between his own conception of selfhood and the phantom limb phenomenon which was both exemplar and problem for Descartes' theory. We, however, can do just that. Locke's formulation of bodily identity, as Quassim Cassam states, specifies that 'To experience a limb as part of oneself is necessary and sufficient for it to

56 K. Joanna S. Forstrom, John Locke and Personal Identity: Immortality and Bodily Resurrection in I7thCentury Philosophy (London: Bloomsbury, 201 I), p. 20.

57 Interestingly, William Bynum notes that Locke advised the Earl of Shaftesbury to try 'powder of sympathy' on three occasions. The implications of this for Locke's philosophy are unclear since the workings of sympathy were themselves up for debate, but it may imply that in practice Locke believed in some form of identity inhering in atoms, or simply that he had tried and approved the remedy himself. See William F. Bynum, 'The Weapon Salve in Seventeenth Century English Drama', Journal of the History of Medicine and Allied Sciences 21:I (I966): Io, https://doi.org/Io . I093/jhmas/XXI.r.8.

58 John Locke, An Essay Concerning Human Understanding, ed. Roger Woolhouse, revised edition (London: Penguin Classics, I998), p. 303. 
be a part of one. 59 Taken to its logical conclusion, then, it implies that phantom limbs - experienced as having feeling, being moved by volition, and so forth in spite of their physical absence - are truly a part of one's body. To a lesser extent, the same could be said of 'incorporated' prostheses, those which, as explored in Chapter 4, become experienced not as an addition to, but rather as a part of the body.

Including phantom limbs in the bodily schema may seem a sticking point for Locke's theory. Viewed from a different perspective, however, Locke's theory of embodiment actually accords neatly with some modern descriptions of phantom limb syndrome. Influenced by Merleau-Ponty and by Leder's theory of the absent body, amputee Vivian Sobchack describes her phantom limb as both objectively absent and subjectively present. That is, while physically absent, her painful and perplexing 'phantom' leg dys-appears to her consciousness, 'figuring itself in odd ways against the ground of where it once had lived its ordinary form of disappearance, its transparent and enabling absence in presence'. ${ }^{60}$ The phantom limb ironically makes its presence felt, not least by animating Sobchack's prosthesis. ${ }^{61}$ By contrast, the healthy, objectively present leg recedes from consciousness:

whereas I subjectively experienced the objective 'no-thing' there of my absent left leg as 'some thing' here [i.e. in her consciousness], I subjectively experienced the objective 'some thing' there of my 'real' leg as almost 'no-thing' here at all ... Despite, and because of, their reversed inflection, there is, then, a mirrored form of structural homology - of recognition and, indeed, of possible reconciliation - that exists between my two legs: the so-called 'phantom' and the so-called 'real' one. ${ }^{62}$

Though it seems counterintuitive, Sobchack's description of 'the presence of an absence' speaks powerfully to Porterfield's account of the phantom limb's 'strong and lively' illusions. Douglas Robinson poetically

59 Quassim Cassam, 'Introspection and Bodily Self-Ascription', in The Body and the Self, ed. Jose Luis Bermudez, Anthony Marcel, and Naomi Eilan (Cambridge: MIT Press, I995), p. 320.

6o Sobchack, 'Living a "Phantom Limb", 57.

61 This relation between phantom and prosthesis is now used to design artificial limbs with proprioceptive feedback. This involves designing the limb such that it utilises remaining movement through the nearest natural joint, an idea known as extended physiological proprioception (EPP). On this and other anomalies of limb perception such as the rubber hand illusion (in which one's hands seem to be moved by somebody else), see Jose Luis Bermudez, 'Ownership and the Space of the Body', in The Subject's Matter: Self-Consciousness and the Body, ed. Frédérique de Vignemont and Adrian J. T. Alsmith (Cambridge: MIT Press, 2017), p. I25.

62 Sobchack, 'Living a "Phantom Limb", 59. 
refers to PLP as a creative transgression of the proprioceptive system which usually helps one to differentiate one's body from the 'outside' world:

The phantom limb phenomenon might even be thought of as proprioception's 'literary' creativity: making the amputee care as deeply about a limb that exists 'only in the imagination' as about one that can be seen and poked and prodded, and indeed infusing the mechanical/scientific artificiality of the prosthetic device with the estranging/enlivening power of the 'only imagined' phantom limb. ${ }^{63}$

Moreover, as Cassandra Crawford has shown, phantoms have the power now, no less than in Descartes' lifetime, to challenge our notions of embodiment. These 'embodied ghosts', she argues, remind us of the limits of rigid theoretical models. ${ }^{64}$ Despite scientific advances, phantom pains remain inchoate subject-objects, which persist in somatic, relational, and social terms, acting on and with the person from whom they are 'absent'.

\section{Conclusion}

Debates about phantom limbs were very different in tone to those about resurrection. Where discussions of the latter were necessarily spiritual, and often poetic, discourses around phantoms strove - with varying degrees of success - for rationalist, mechanistic explanations of this mysterious phenomenon. This emphasis was both a product of and cause for the fascination of Enlightenment thinkers with phantom limb syndrome; to explain this phenomenon would be to delineate and tame the irrational and unruly body. This project has continued intermittently ever since. In the eighteenth century, John Hunter reported two cases of phantom sensations in a missing penis. He interpreted these in a broadly similar way to Descartes, speculating that stimulation of a nerve would produce the same sensation regardless of where along the nerve that stimulation was received. ${ }^{65}$ In the 1800 , Silas Weir Mitchell coined the phrase

63 Douglas Robinson, Estrangement and the Somatics of Literature: Tolstoy, Shklovsky, Brecht (Baltimore: Johns Hopkins University Press, 2008), pp. I03-4.

64 Cassandra S. Crawford, 'Body Image, Prostheses, Phantom Limbs', Body and Society 2 I:2 (20 I 5): 22 I-44, https://doi.org/I0.I I77/I357034XI4522102; Cassandra S. Crawford, "“You Don't Need a Body to Feel a Body": Phantom Limb Syndrome and Corporeal Transgression', Sociology of Health and Illness 35:3 (2013): 434-48, https://doi.org/I0.I I I /j.I 467-9566.20 I 2.0 I 498.x.

65 Nicholas J. Wade, 'The Legacy of Phantom Limbs', Perception 32:5 (2003): 52 I, https://doi.org/ Io . I068/p3205ed. 
'phantom limb'. ${ }^{66}$ Neurological research in this area continues, most notably in V. S Ramachandran's use of mirrors to induce synaesthesia of the phantom limb with its 'real' counterpart. ${ }^{67}$ At length, however, many of the questions raised by these experiments are similar to those posed by Descartes and his early modern counterparts: how can our feelings be 'all in the mind'? What makes my body mine? These queries stretch the limits of the imagination, and blur the boundaries between medicine, philosophy, and faith.

66 Ibid., 5 I I. On the history of phantom limb syndrome, see Douglas B. Price and Neil J. Twombly, The Phantom Limb Phenomenon: a Medical, Folkloric, and Historical Study. Texts and Translations of Ioth to 2oth Century Accounts of the Miraculous Restoration of Lost Body Parts (Washington: Georgetown University Press, I978); Nicholas J. Wade and Stanley Finger, 'William Porterfield (ca. I696-I77I) and his Phantom Limb: an Overlooked First Self-Report by a Man of Medicine', Neurosurgery 52:5 (2003): I I 96-9, https://doi.org/I O. I 227/or.NEU.0000057837.74I 42.68;.

67 V. S. Ramachandran and D. Rogers-Ramachandran, 'Synaesthesia in Phantom Limbs Induced with Mirrors', Proceedings: Biological Sciences 263:1 369 (1996): 377-86. 